\title{
Proteomics and Transcriptomics of the Hippocampus and Cortex in SUDEP and High-Risk SUDEP Patients
}

Dominique F. Leitner, PhD, * James D. Mills, PhD, * Geoffrey Pires, MS,* Arline Faustin, MD, Eleanor Drummond, PhD, Evgeny Kanshin, PhD, Shruti Nayak, MS, Manor Askenazi, PhD, Chloe Verducci, BA, Bei Jun Chen, PhD, Michael Janitz, PhD, Jasper J. Anink, BSc, Johannes C. Baayen, MD, Sander Idema, MD, PhD, Erwin A. van Vliet, PhD, Sasha Devore, PhD, Daniel Friedman, MD, MSc, Beate Diehl, MD, PhD, Catherine Scott, MPhil, Roland Thijs, MD, PhD, Thomas Wisniewski, MD, Beatrix Ueberheide, PhD, Maria Thom, MD, Eleonora Aronica, MD, PhD, and Orrin Devinsky, MD

Neurology ${ }^{\circledR}$ 2021;96:e2639-e2652. doi:10.1212/WNL.0000000000011999

\section{Abstract}

\section{Objective}

To identify the molecular signaling pathways underlying sudden unexpected death in epilepsy (SUDEP) and high-risk SUDEP compared to control patients with epilepsy.

\section{Methods}

For proteomics analyses, we evaluated the hippocampus and frontal cortex from microdissected postmortem brain tissue of 12 patients with SUDEP and 14 with non-SUDEP epilepsy. For transcriptomics analyses, we evaluated hippocampus and temporal cortex surgical brain tissue from patients with mesial temporal lobe epilepsy: 6 low-risk and 8 high-risk SUDEP as determined by a short ( $<50$ seconds) or prolonged ( $\geq 50$ seconds) postictal generalized EEG suppression (PGES) that may indicate severely depressed brain activity impairing respiration, arousal, and protective reflexes.

\section{Results}

In autopsy hippocampus and cortex, we observed no proteomic differences between patients with SUDEP and those with non-SUDEP epilepsy, contrasting with our previously reported robust differences between epilepsy and controls without epilepsy. Transcriptomics in hippocampus and cortex from patients with surgical epilepsy segregated by PGES identified 55 differentially expressed genes (37 protein-coding, 15 long noncoding RNAs, 3 pending) in hippocampus.

\section{Conclusion}

The SUDEP proteome and high-risk SUDEP transcriptome were similar to those in other patients with epilepsy in hippocampus and cortex, consistent with diverse epilepsy syndromes and comorbid conditions associated with SUDEP. Studies with larger cohorts and different epilepsy syndromes, as well as additional anatomic regions, may identify molecular mechanisms of SUDEP.

\author{
Correspondence \\ Dr. Devinsky \\ Orrin.Devinsky@ \\ nyulangone.org
}




\section{Glossary}

ERMN = Ermin; FCD $=$ focal cortical dysplasia FDR $=$ false discovery rate; FFPE $=$ formalin-fixed paraffin-embedded; GDNF = glial cell-derived neurotrophic factor; GTCS = generalized tonic-clonic seizure; LC = liquid chromatography; LCM = laser capture microdissection; LFQ = label-free quantification; lncRNA = long noncoding RNA; MBP = myelin basic protein; MS = mass spectrometry; MTLE = mesial temporal lobe epilepsy; NASR = North American SUDEP Registry; PCA = principal component analysis; PGES = postictal generalized EEG suppression; RNAseq = RNA-sequencing; SUDEP = sudden unexpected death in epilepsy.

Sudden unexpected death in epilepsy (SUDEP) affects 1 in 1,000 patients with epilepsy annually and is the leading cause of epilepsy-related deaths. ${ }^{1}$ SUDEP most often follows a generalized tonic-clonic seizure (GTCS) and excludes trauma, drowning, status epilepticus, or other causes. Most deaths are unwitnessed and occur during sleep, and the patient is found prone.

Studies on SUDEP epidemiology, risk factors, mechanisms, and prevention have advanced our understanding, although pathophysiologic understanding remains limited. ${ }^{2,3}$ After a GTCS, prolonged ( $>50$ seconds) postictal generalized EEG suppression (PGES) may increase SUDEP risk and may be a SUDEP biomarker because severe, prolonged reduced brain activity impairs arousal, respiration, and other autonomic functions. ${ }^{4}$ However, we cannot predict why some low-risk patients become patients with SUDEP, high-risk patients survive for decades, and other patients succumb to SUDEP despite recovering from many earlier GTCS. Patients with SUDEP may harbor pathogenic gene variants in brain and heart ion channels, ${ }^{5-7}$ but a role in SUDEP pathogenesis remains speculative. Animal models of genetic epilepsies and chemo-induced seizures implicate abnormalities in respiration, arousal, and parasympathetic hyperactivity in SUDEP pathogenesis. ${ }^{1,8-10}$ However, the neuropathology of SUDEP parallels findings in patients with non-SUDEP epilepsy. ${ }^{11,12}$ Potential proteomic and transcriptional molecular signatures associated with SUDEP have not been studied.

Our study investigated the molecular signaling networks associated with SUDEP in brain regions implicated in ictogenesis, ${ }^{13}$ from localized proteomics in autopsy hippocampal CA1-3, dentate gyrus, and frontal cortex from patients with SUDEP and patients with non-SUDEP epilepsy and transcriptomics in hippocampus and temporal cortex from lowand high-risk SUDEP (PGES $<50$ or $\geq 50$ seconds) epilepsy surgical tissue.

\section{Methods}

\section{Standard Protocol Approvals, Registrations, and Patient Consents}

Autopsy brain tissue and clinical information from patients with SUDEP or non-SUDEP epilepsy were obtained with approval by the New York University School of Medicine Institutional Review Board. All next of kin provided written informed consent.

\section{Human Brain Tissue for Proteomics}

Postmortem brain tissue from patients with epilepsy who died of SUDEP or other causes was obtained through the North American SUDEP Registry (NASR), which began enrolling patients in October 2011, ${ }^{2}$ with approval by the New York University School of Medicine Institutional Review Board. Causes of death were classified (O.D., D.F.) into non-SUDEP epilepsy and SUDEP (definite SUDEP, definite SUDEP plus, and probable SUDEP). ${ }^{1,2}$ Lifetime GTCS history was determined from interviews and medical records, representing the best estimate for each patient and as described previously for these patients. ${ }^{2}$ After neuropathologic review (T.W., A.F.), brain tissue was processed into formalin-fixed paraffin-embedded (FFPE) blocks and sections were stained with luxol fast blue counterstained with hematoxylin \& eosin. Archival time for brain tissue storage in formalin was $\leq 3$ years; thus, patients were chosen from those who were enrolled in NASR between July 2014 to March 2017. Patients were age and sex matched from available NASR cases. There were no significant differences in age at death ( $p=0.9190$, unpaired $t$ test), disease duration ( $p=$ $0.7295)$, disease onset $(p=0.4797)$, or sex $(p>0.9999)$. Clinical and neuropathologic data on the 14 patients with non-SUDEP epilepsy and 12 with SUDEP are summarized in table 1. Group sizes were determined from the number of patients with significant findings as previously reported, ${ }^{14-16}$ including our earlier studies in patients with epilepsy with similar methods. ${ }^{17,18}$

\section{Laser Capture Microdissection for Proteomics}

FFPE brain tissue blocks containing either hippocampus (lateral geniculate nucleus level $)^{19}$ or superior frontal gyrus were sectioned at $8 \mu \mathrm{m}$ and collected onto laser capture microdissection (LCM)-compatible PET slides (Leica, Newcastle, UK). Sections were stained with cresyl violet to localize regions of interest for $\mathrm{LCM}^{20}$ and air dried overnight in a loosely closed container. LCM was used to individually microdissect $10 \mathrm{~mm}^{2}$ from the hippocampal CA1-3 region and superior frontal cortex (layers I-IV), and $4 \mathrm{~mm}^{2}$ from the hippocampal dentate gyrus into liquid chromatography (LC)-mass spectrometry (MS)-grade water (Thermo Scientific, Waltham, MA). Microdissected samples were centrifuged for 2 minutes at $14,000 \mathrm{~g}$ and stored at $-80^{\circ} \mathrm{C}$. LCM was performed at $5 \times$ magnification with an LMD6500 microscope equipped with an ultraviolet laser (Leica).

\section{Label-Free Quantitative MS Proteomics}

Label-free quantitative MS assessed differential protein expression as described previously. ${ }^{18,21,22}$ FFPE cuts were 
Table 1 Patients With Epilepsy and SUDEP in Proteomics Analyses

\begin{tabular}{|c|c|c|c|c|c|c|c|c|c|c|}
\hline ID & $\begin{array}{l}\text { Age, } \\
\text { y }\end{array}$ & Sex & $\begin{array}{l}\text { Age at } \\
\text { onset, } \\
\text { y }\end{array}$ & $\begin{array}{l}\text { Disease } \\
\text { duration, } \\
\text { y }\end{array}$ & $\begin{array}{l}\text { Seizure } \\
\text { type }\end{array}$ & $\begin{array}{l}\text { Total } \\
\text { lifetime } \\
\text { GTCS }\end{array}$ & $\begin{array}{l}\text { COD and SUDEP } \\
\text { status }\end{array}$ & $\begin{array}{l}\text { PMI, } \\
\text { h }\end{array}$ & $\begin{array}{l}\text { Relevant } \\
\text { neuropathology }\end{array}$ & $\begin{array}{l}\text { Brain } \\
\text { region }\end{array}$ \\
\hline \multicolumn{11}{|c|}{ Epilepsy } \\
\hline 1 & 36 & M & 29 & 8 & Unclassified & $10-100$ & $\begin{array}{l}\text { Overdose/ } \\
\text { intoxication }\end{array}$ & 20 & & $\mathrm{HP}, \mathrm{DG}, \mathrm{FC}$ \\
\hline 2 & 54 & $\mathrm{M}$ & 28 & 1 & ND & $<10$ & Accident/trauma & $<24$ & $\begin{array}{l}\text { Mild gliosis, contusion, } \\
\text { disorganization }\end{array}$ & $\mathrm{HP}, \mathrm{DG}$ \\
\hline 3 & 64 & $\mathrm{~F}$ & ND & ND & $\begin{array}{l}\text { Generalized, } \\
\text { unclassified }\end{array}$ & ND & Overdose & 18 & & $H P, D G$ \\
\hline 4 & 50 & M & 0.5 & 49.5 & Focal & $100-500$ & $\begin{array}{l}\text { Choking on foreign } \\
\text { object }\end{array}$ & 15 & & FC \\
\hline 5 & 9 & $\mathrm{~F}$ & 1.5 & 8 & ND & $10-100$ & Drowning & 30 & FCD $\| A$ & $\mathrm{HP}, \mathrm{DG}$ \\
\hline 6 & 45 & M & 25 & 20 & Focal & $10-100$ & Suicide & 27 & Dysgenesis & $\mathrm{HP}, \mathrm{DG}$ \\
\hline 7 & 36 & M & 24 & 12 & Focal & $<10$ & Drowning & 48 & Sclerosis & $\mathrm{HP}, \mathrm{DG}, \mathrm{FC}$ \\
\hline 8 & 45 & M & 2 & 43 & Unclassified & $<10$ & Suicide & $<48$ & & $\mathrm{HP}, \mathrm{DG}, \mathrm{FC}$ \\
\hline 9 & 24 & $\mathrm{~F}$ & ND & ND & ND & ND & Drowning & $<48$ & Dysgenesis & $\mathrm{HP}, \mathrm{DG}, \mathrm{FC}$ \\
\hline 10 & 28 & $\mathrm{M}$ & 5 & 22 & Unclassified & ND & Accident/trauma & $<48$ & Dysgenesis & $\mathrm{HP}, \mathrm{DG}, \mathrm{FC}$ \\
\hline 11 & 22 & $M$ & ND & ND & Unclassified & ND & Drowning & $<48$ & FCD IA & $\mathrm{HP}, \mathrm{DG}, \mathrm{FC}$ \\
\hline 12 & 34 & $\mathrm{~F}$ & 1.5 & 32 & Focal & $10-100$ & $\begin{array}{l}\text { Pulmonary } \\
\text { embolism }\end{array}$ & 13 & FCD IB & $\mathrm{HP}, \mathrm{DG}, \mathrm{FC}$ \\
\hline 13 & 32 & M & 19 & 10 & ND & ND & $\begin{array}{l}\text { Ethanol intoxication } \\
\text { and clobazam } \\
\text { overdose }\end{array}$ & 19 & $\begin{array}{l}\text { FCD IIA, Wernicke } \\
\text { encephalopathy }\end{array}$ & $\mathrm{HP}, \mathrm{DG}, \mathrm{FC}$ \\
\hline 14 & 49 & $M$ & 0.6 & 48.4 & Unclassified & ND & Aspiration & 43 & $\begin{array}{l}\text { Dysgenesis, sclerosis, } \\
\text { gliosis, hemisphere } \\
\text { atrophy }\end{array}$ & $\mathrm{HP}, \mathrm{DG}, \mathrm{FC}$ \\
\hline
\end{tabular}

SUDEP

\begin{tabular}{|c|c|c|c|c|c|c|c|c|c|c|}
\hline 1 & 48 & $M$ & 46 & 2 & Focal & $<10$ & Definite SUDEP plus & $<72$ & & $H P, D G, F C$ \\
\hline 2 & 45 & $\mathrm{~F}$ & 10 & 35 & Focal & $10-100$ & Definite SUDEP & 49 & FCD IA & $\mathrm{HP}, \mathrm{DG}, \mathrm{FC}$ \\
\hline 3 & 48 & M & 0.8 & 42 & Focal & $100-500$ & Definite SUDEP & $<48$ & FCD IA, dysgenesis & $H P, D G, F C$ \\
\hline 4 & 27 & M & 13 & 14 & Generalized & $10-100$ & Probable SUDEP & $<48$ & FCD $\| A$ & $\mathrm{HP}, \mathrm{DG}, \mathrm{FC}$ \\
\hline 5 & 32 & M & 18 & 10 & $\begin{array}{l}\text { Generalized, } \\
\text { unclassified }\end{array}$ & $100-500$ & Probable SUDEP & $<48$ & Mild FCD ॥A, gliosis & $\mathrm{HP}, \mathrm{DG}, \mathrm{FC}$ \\
\hline 6 & 20 & $\mathrm{~F}$ & 9 & 11 & $\begin{array}{l}\text { Generalized, } \\
\text { unclassified }\end{array}$ & $10-100$ & Definite SUDEP & $<48$ & Dysgenesis & $H P, D G, F C$ \\
\hline 7 & 28 & M & 27 & 1 & Focal & $<10$ & Definite SUDEP & 25 & Dysgenesis & $\mathrm{HP}, \mathrm{DG}, \mathrm{FC}$ \\
\hline 8 & 30 & $\mathrm{~F}$ & ND & ND & Unclassified & ND & Definite SUDEP & 23 & & $\mathrm{HP}, \mathrm{DG}, \mathrm{FC}$ \\
\hline 9 & 55 & M & 5 & 50 & Focal & ND & Definite SUDEP plus & $<48$ & Sclerosis, infarct & $H P, D G, F C$ \\
\hline 10 & 20 & M & 9 & 11 & ND & 0 & Definite SUDEP & $<48$ & FCD $\| A$ & $\mathrm{HP}, \mathrm{DG}, \mathrm{FC}$ \\
\hline 11 & 44 & M & 4 & 40 & Unclassified & ND & Definite SUDEP & $<48$ & FCD $\| A$ & HP, DG, FC \\
\hline 12 & 49 & $\mathrm{~F}$ & 41 & 9 & Unclassified & $<10$ & Definite SUDEP & $<24$ & Venous angioma & $H P, D G, F C$ \\
\hline
\end{tabular}

Abbreviations: COD = cause of death; DG = dentate gyrus; FC = frontal cortex; FCD = focal cortical dysplasia; GTCS = generalized tonic-clonic seizure; HP = hippocampus; ID = identification; ND = not determined; PMI = postmortem interval; SUDEP = sudden unexplained death in epilepsy.

Dysgenesis is dysgenesis of the hippocampal dentate gyrus; sclerosis is hippocampal sclerosis. 
incubated in $50 \mathrm{mM}$ ammonium bicarbonate solution containing $20 \%$ (vol/vol) acetonitrile for 1 hour at $95^{\circ} \mathrm{C}$ followed by 2 hours at $65^{\circ} \mathrm{C}$. Disulfide bonds were reduced with $10 \mathrm{mMDTT}$ ( 1 hour at $57^{\circ} \mathrm{C}$ ) and alkylated with $30 \mathrm{mM}$ iodoacetamide (45 minutes at room temperature in the dark). Proteins were enzymatically digested into peptides with $300 \mathrm{ng}$ trypsin (sequencing grade, Promega, Madison, WI) overnight at room temperature. Digestions were quenched by acidification with trifluoroacetic acid, and peptides were concentrated and desalted on POROS R2 C18 beads. Eluates were dried in a speedvac and resuspended in $0.5 \%$ acetic acid $(\mathrm{AcOH})$. LC separation was performed online on EASY-nLC 1200 (Thermo Scientific) with the use of an Acclaim PepMap $100(75 \mu \mathrm{m} \times 2 \mathrm{~cm})$ precolumn and a PepMap RSLC C18 $(2 \mu \mathrm{m}, 100 \mathrm{~A} \times 50 \mathrm{~cm})$ analytical column. Peptides were gradient eluted from the column directly into the Orbitrap Fusion Lumos mass spectrometer using a 165-minute acetonitrile gradient $(\mathrm{A}=2 \%$ acetonitrile in $0.5 \% \mathrm{AcOH} / \mathrm{B}=80 \%$ acetonitrile in $0.5 \% \mathrm{AcOH})$. The flow rate was set at $200 \mathrm{~nL} / \mathrm{min}$. The mass spectrometer was operated in a data-dependent acquisition mode. High-resolution full MS spectra were acquired with a resolution of 240,000, an automatic gain control (AGC) target of $1 \mathrm{e} 6$, with a maximum ion injection time of 50 milliseconds, and scan range of 400 to $1,500 \mathrm{~m} / \mathrm{z}$. After each full MS scan, datadependent HCD MS/MS scans were acquired in the ion trap (scan rate rapid, AGC target of $2 \mathrm{e} 4$, normalized collision energy of 32). Precursor isolation window was set at $2 \mathrm{Da}$.

\section{Proteomics Computational Analysis}

MS data were analyzed as previously described. ${ }^{18,21,22}$ Raw MS data were processed using the MaxQuant ${ }^{23}$ software (version 1.6.3.4) and the SwissProt human protein database (uniprot.org) containing 20,421 entries. A database including a common list of common laboratory contaminants (248 entries) was also used in the search. All peptide-spectrum matches and peptide and protein identifications were filtered to get a desired false discovery rate (FDR) level < $1 \%$ (calculated with the decoy database approach). For the MS/MS search, enzyme specificity was set to trypsin (up to 2 miscleavages), and precursor mass tolerance was set to $20 \mathrm{ppm}$ with subsequent nonlinear mass recalibration. Carbamidomethylation of cysteine was set as a fixed modification; protein $\mathrm{N}$-term acetylation and methionine oxidation were set as variable modifications. Match between runs algorithm was enabled to transfer peptide feature identifications between MS runs based on LC retention time (0.7-minute tolerance after initial recalibration) and precursor mass tolerance. Labelfree quantification (LFQ) was performed with a built-in maxLFQ algorithm, ${ }^{24}$ and normalization was performed separately for all samples within each region of interest.

Data analysis was performed in Perseus framework ${ }^{25}$ (perseusframework.org/), R environment (r-project.org/, Vienna, Austria), or GraphPad Prism (La Jolla, CA).

\section{Proteomics Statistical Analyses}

The protein expression matrix $(n=4,129)$ was filtered to contain only proteins that were quantified in $\geq 8$ replicates in at least 1 condition (SUDEP or non-SUDEP epilepsy) in any brain region $(n=2,847)$. Subsequently missing values were imputed from the intensity distribution-simulated lowintensity protein features (width of 0.3 and downshift of 1.8 relative to measured protein intensity distribution). An unpaired 2-tailed $t$ test was performed for PCA1 in each brain region to determine the significance of separation in the patients with SUDEP and non-SUDEP epilepsy. All other analyses were done using nonimputed data. A Student 2-sample $t$ test was used to assess statistical significance of the changes in protein abundance between conditions. Obtained $p$ values were adjusted for multiple hypothesis testing using permutationbased FDR to a cutoff of 5\%. Cell type-specific annotations were included in the data available on Dryad (table e- 3 , doi. org/10.5061/dryad.dfn2z3508) and on volcano plots in figure $1, \mathrm{~F}$ through $\mathrm{H}$, derived from previous data. ${ }^{26}$ Annotations were included when a protein had only 1 associated cell type after removing cerebellar annotations and when the annotation included $>1$ associated cell type (both excitatory and inhibitory neuron annotations) and were thus assigned a general neuron annotation, for a total of 1,066 possible annotations.

\section{Proteomics Correlation}

For the correlation in protein abundance between conditions and brain regions, we used averaged LFQ values. A Pearson correlation was calculated for proteins detected in both patients with SUDEP and those with non-SUDEP epilepsy for each brain region, with 2,715 proteins for hippocampal CA13, 2,464 proteins for dentate gyrus, and 2,695 proteins for the frontal cortex.

\section{Immunohistochemistry}

Immunohistochemistry was performed to validate the identified protein of interest, ermin (ERMN) as previously described. ${ }^{18,27}$ Briefly, FFPE sections $(8 \mu \mathrm{m})$ were deparaffinized and rehydrated through a series of xylenes and ethanol dilutions. Heat-induced antigen retrieval was performed with $10 \mathrm{mM}$ sodium citrate and $0.05 \%$ triton-x 100, pH6. Blocking with $10 \%$ normal donkey serum was followed by ERMN primary antibody (1:200, Sigma HPA038295) overnight at $4^{\circ} \mathrm{C}$. Sections were incubated with donkey anti-rabbit AlexaFluor 647 secondary antibody (1:500, ThermoFisher Invitrogen, Carlsbad, CA) and coverslipped.

\section{Image Semiquantitative Analysis}

Whole slide scanning was performed at $20 \times$ magnification with a NanoZoomer HT2 (Hamamatsu) microscope using the same settings for each slide. One image containing the hippocampal CA1-3 region was collected for each patient, 11 with non-SUDEP epilepsy and 11 with SUDEP. Images were analyzed in Fiji ImageJ to compare the amount of ERMN in patients with SUDEP and non-SUDEP epilepsy. The same binary threshold was used for all images to determine the number of ERMN-positive pixels in each image, which was reported as a percentage of the total image area. An unpaired $t$ test was performed for statistical analysis; a value of $p<0.05$ was considered significant. 


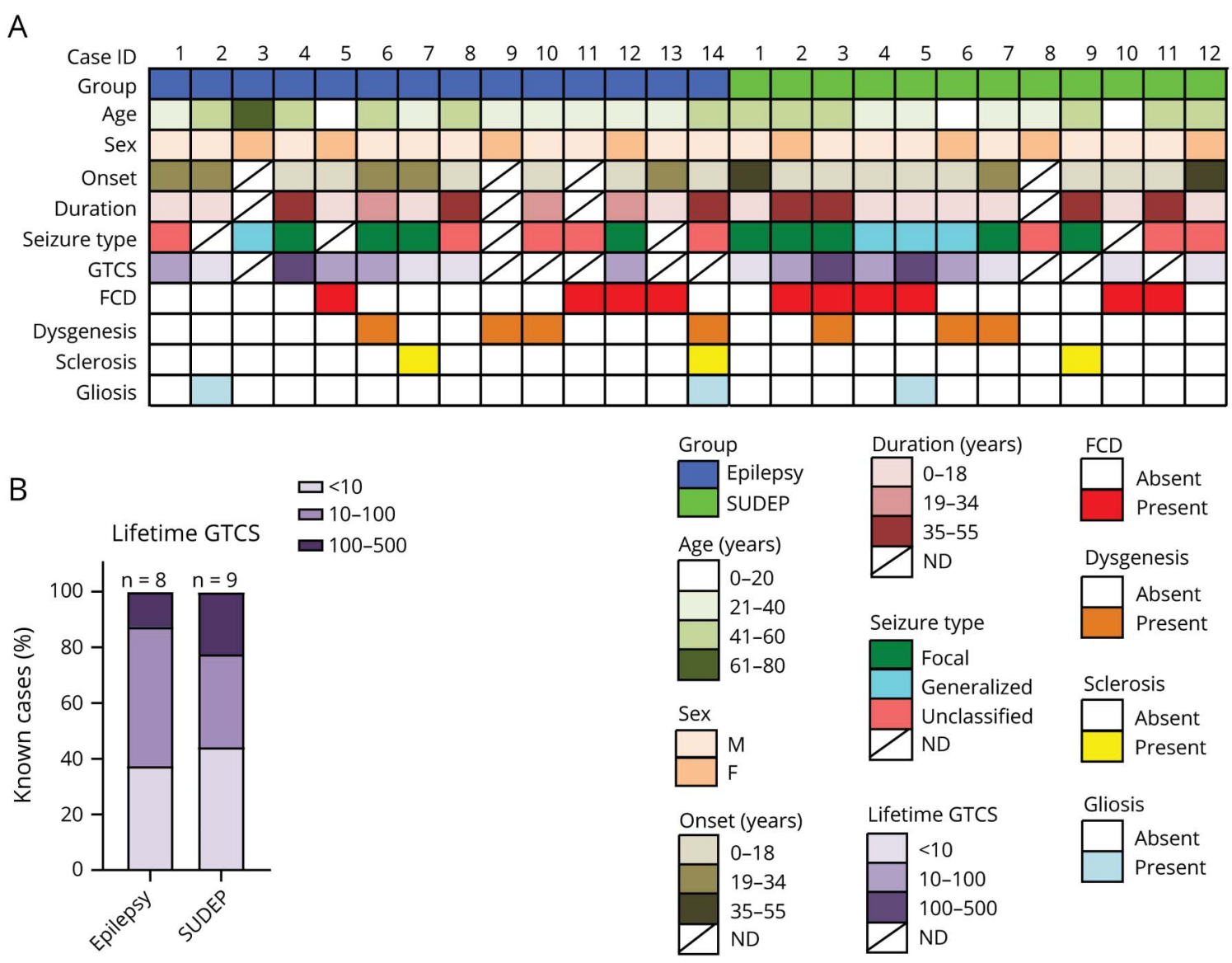

(A) Patient history is summarized for patients with sudden unexpected death in epilepsy (SUDEP) and non-SUDEP epilepsy. (B) A summary of lifetime generalized tonic-clonic seizure (GTCS) history burden for the patients in this study with known information. ID = identification.

Confocal imaging was used to collect representative images of ERMN immunohistochemistry using a Zeiss LSM880 confocal microscope with the same settings on each slide with a PlanApochromat 20x/0.8 M27 objective and a pinhole of $38 \mu \mathrm{m}$.

\section{RNA-Sequencing Datasets}

Small RNA-sequencing (RNAseq) and RNAseq datasets were retrieved form the European Genome-Phenome Archive (accession No. EGAS00001003922) from patients with mesial temporal lobe epilepsy (MTLE) undergoing surgical resection and with available PGES duration $>1$ second. ${ }^{17}$ The patients were age and sex matched, with no significant differences in age at surgery $(p=0.6622$, unpaired $t$ test $)$, disease duration ( $p=$ $0.4391)$, disease onset $(p=0.4612)$, or sex $(p>0.9999)$. Small RNAseq and RNAseq data were retrieved for 6 patients with PGES $<50$ seconds, indicating a potential low risk for SUDEP, and 8 patients with PGES $\geq 50$ seconds, indicating a potential high risk for SUDEP as previously described. ${ }^{4}$ Table 2 summarizes the clinical characteristics of these patients. PGES occurrence and duration was assessed by 2 epileptologists (C.S., R.T.).

\section{Bioinformatic Analysis of RNAseq Data}

Bioinformatic analysis was performed as described previously. ${ }^{17}$ Briefly, library normalization and differential expression testing were carried out with the $\mathrm{R}$ package DESeq2. The Wald test identified differentially expressed genes using a BenjaminiHochberg-adjusted value of $p<0.05$ for significance. Cell type-specific annotations were included (Dryad tables e- 4 and e-5, doi.org/10.5061/dryad.dfn2z3508) and on volcano plots in figures $2, \mathrm{C}$ and $\mathrm{E}$, derived from previous data. ${ }^{26}$ Annotations were included when a gene had only 1 associated cell type after removal of cerebellar annotations and when the annotation included $>1$ associated cell type (both excitatory and inhibitory neuron annotations) and were thus assigned a general neuron annotation, for a total of 1,066 possible annotations.

A Reactome pathway enrichment analysis was performed with the $\mathrm{R}$ package ReactomePA. The differentially expressed genes from the RNAseq differential expression analysis were put into $\mathrm{R}$ and tested for overrepresentation of enriched Reactome pathways using hypergeometric testing. Pathways with a Benjamini-Hochberg-corrected value of $p<0.05$ were considered significantly enriched.

\section{Bioinformatic Analysis of Small RNAseq Data}

Bioinformatic analysis of the small RNAseq data was performed as described previously. ${ }^{17}$ Briefly, library normalization and differential expression testing were carried out with the $\mathrm{R}$ 
Table 2 Epilepsy Patients With Low or High Risk of SUDEP in RNAseq Analyses

\begin{tabular}{|c|c|c|c|c|c|c|c|}
\hline ID & $\begin{array}{l}\text { Age at } \\
\text { surgery, y }\end{array}$ & Sex & $\begin{array}{l}\text { Age at } \\
\text { onset, y }\end{array}$ & $\begin{array}{l}\text { Disease } \\
\text { duration, y }\end{array}$ & $\begin{array}{l}\text { Seizure type } \\
\text { before GTCS }\end{array}$ & $\begin{array}{l}\text { PGES } \\
\text { length, s }\end{array}$ & $\begin{array}{l}\text { Brain } \\
\text { region }\end{array}$ \\
\hline \multicolumn{8}{|c|}{ PGES $<50 \mathrm{~s}$} \\
\hline 1 & 34 & M & 19 & 15 & Focal with motor & 3 & TC \\
\hline 2 & 22 & M & 7 & 15 & Focal with motor & 37 & TC \\
\hline 3 & 33 & $\mathrm{~F}$ & 9 & 24 & Focal with motor & 24 & $\mathrm{HP}, \mathrm{TC}$ \\
\hline 4 & 33 & $\mathrm{~F}$ & 22 & 11 & Focal with motor & 43 & $\mathrm{HP}$ \\
\hline 5 & 58 & M & 51 & 7 & Focal without motor & 2 & $\mathrm{HP}$ \\
\hline 6 & 29 & $\mathrm{~F}$ & 13 & 16 & Focal to bilateral tonic-clonic & 49 & $\mathrm{HP}$ \\
\hline \multicolumn{8}{|c|}{ PGES $\geq 50 \mathrm{~s}$} \\
\hline 1 & 30 & M & 21 & 9 & Focal with motor & 62 & $\mathrm{HP}, \mathrm{TC}$ \\
\hline 2 & 53 & M & 0 & 53 & Focal with motor & 73 & $\mathrm{HP}, \mathrm{TC}$ \\
\hline 3 & 55 & $\mathrm{~F}$ & 20 & 35 & Focal without motor & 51 & $\mathrm{HP}$ \\
\hline 4 & 32 & $\mathrm{~F}$ & 15 & 17 & Focal with motor & 52 & $\mathrm{HP}$ \\
\hline 5 & 45 & $\mathrm{~F}$ & 23 & 22 & Focal with motor & 52 & $\mathrm{HP}$ \\
\hline 6 & 37 & M & 8 & 11 & Focal with motor & 54 & $\mathrm{HP}$ \\
\hline 7 & 25 & M & 18 & 7 & Focal to bilateral tonic-clonic & 51 & $\mathrm{HP}$ \\
\hline 8 & 25 & M & 17 & 8 & Focal without motor & 62 & HP \\
\hline
\end{tabular}

Abbreviations: GTCS = generalized tonic-clonic seizure; HP = hippocampus; ID = identification; PGES = postictal generalized EEG suppression; RNAseq = RNA sequencing; SUDEP = sudden unexplained death in epilepsy; TC = temporal cortex.

package DESeq2. The Wald test identified differentially expressed genes with a Benjamini-Hochberg-adjusted value of $p<0.05$ considered significant.

\section{RNAseq Validation by Quantitative PCR}

The gene expression of glial cell-derived neurotrophic factor (GDNF) family receptor alpha 1 (GFRA1) was assessed in the same cohort of samples used in the RNAseq analysis for which sufficient RNA remained (PGES $<50$ seconds, $n=4$, PGES $\geq 50$ seconds, $n=7$ ). $P C R$ primers based on the reported cDNA sequences were designed using the National Center for Biotechnology Information primer design tool. ${ }^{28}$ The sequences for the forward and reverse primers of GFRA1 were $5^{\prime}$-TCT TCC AGC CGC AGA AGA AC-3' and 5'-AAC AGT GGG GAC AAA CTG GG-3', respectively. Total RNA (700 ng) was reverse transcribed into $\mathrm{CDNA}$ using oligodT primers. For each quantitative PCR reaction, a mastermix was prepared as follows: $1 \mu \mathrm{L}$ cDNA, $2.5 \mu \mathrm{L}$ of $2 \times$ SensiFAST SYBR Green Reaction Mix (Bioline Inc, Taunton, MA), and $0.2 \mu \mathrm{M}$ of both the reverse and forward primers. The PCRs were run on a Roche Lightcycler 480 thermocycler (Roche Applied Science, Basel, Switzerland). Each sample and primer pair were run in triplicates. Data quantification was performed as previously described ${ }^{17}$ relative to the reference genes, eukaryotic translation elongation factor 1 alpha 1 (EEF1A1) and chromosome 1 open reading frame 43 (Clorf43). The normalized ratio was compared between the 2 groups (Mann-Whitney $U$ test); values of $p<0.05$ were considered significant.

\section{Data Availability}

All data needed to evaluate the conclusions in the paper are present in the paper and on Dryad at doi.org/10.5061/dryad. dfn2z3508. Additional data related to this article may be requested from the authors.

\section{Results}

\section{Proteome of Patients With SUDEP and Non- SUDEP Epilepsy Autopsy}

The differential expression of proteins in patients with SUDEP $(\mathrm{n}=12)$ and non-SUDEP $(\mathrm{n}=14)$ was evaluated in autopsy tissue using label-free quantitative MS in the microdissected hippocampal CA1-3 region, dentate gyrus, and frontal cortex because these regions have been implicated in ictogenesis and may also be influenced by seizure activity. ${ }^{13}$ Patient histories are summarized in table 1 and figure $1, \mathrm{~A}$ and B. A principal component analysis (PCA) did not distinguish patients with SUDEP and those with non-SUDEP epilepsy in any of the studied brain regions (figure $2, \mathrm{~A}-\mathrm{C}$ ). The main source of variation in these patients, PCA1, did not show a significant difference when patients with SUDEP and non- 
Figure 2 Proteomics PCA Analyses in Hippocampus, Dentate Gyrus, and Frontal Cortex of Patients With SUDEP and NonSUDEP Epilepsy

A. Hippocampal CA1-3

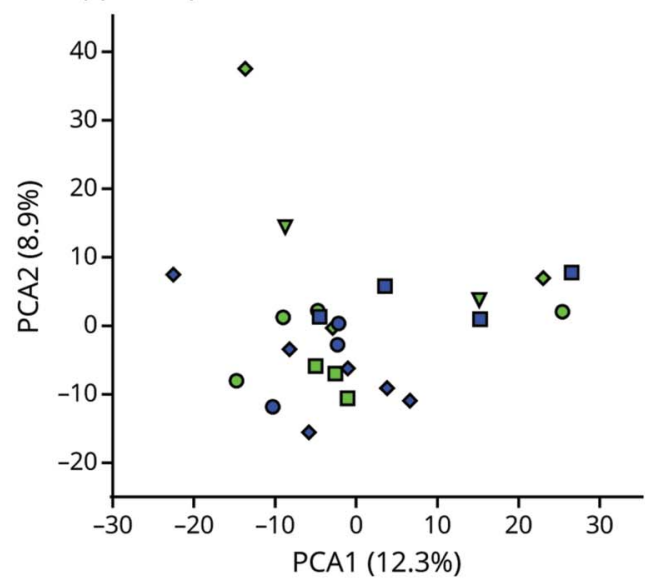

C. Frontal cortex

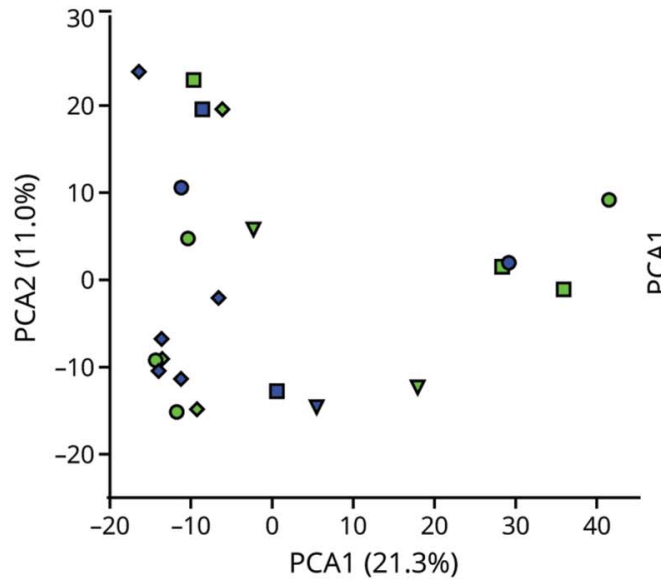

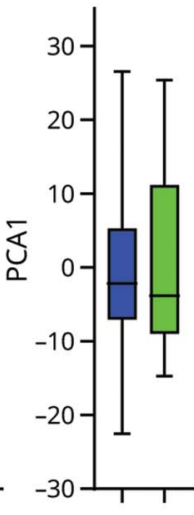

B. Dentate gyrus
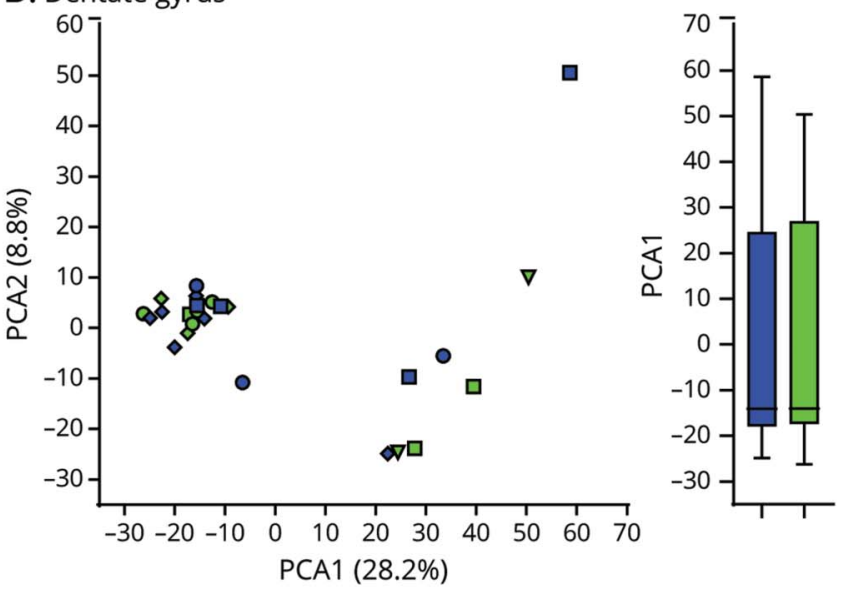

(A-C) A principal component analysis (PCA) of the proteomics analyses shows the indicated variation in each brain region of patients with sudden unexpected death in epilepsy (SUDEP) $(n=12)$ and non-SUDEP epilepsy $(n=14)$. There is no separation by SUDEP status or lifetime generalized tonic-clonic seizure (GTCS) history burden. An unpaired 2-tailed $t$ test of PCA1 between the SUDEP and non-SUDEP epilepsy groups in each brain region was not significant, as depicted by a boxplot with bars indicating minimum and maximum values. ND = not determined.

SUDEP were compared in each brain region by an unpaired 2 -tailed $t$ test, as depicted by a box plot in figure 2, A through C. Lifetime GTCS burden, associated with an increased SUDEP risk, ${ }^{1}$ was evaluated to determine whether this factor may contribute to protein differences as seen by a separation of groups. From patients with available data (9 with SUDEP and 8 with non-SUDEP epilepsy), 55.6\% of those with SUDEP and $62.5 \%$ of those with non-SUDEP epilepsy had $>10$ lifetime GTCS, and $22.2 \%$ of those with SUDEP and $12.5 \%$ of patients with non-SUDEP epilepsy had $>100$ lifetime GTCS. Lifetime GTCS frequency did not contribute to group differences in the PCA (figure 2, A-C). There was no enrichment in patients with SUDEP or non-SUDEP epilepsy with $>10$ or $>100$ lifetime GTCS by a Fisher exact test. Furthermore, in the PCA, there was no relationship of SUDEP status to neuropathology (focal cortical dysplasia [FCD, $\mathrm{n}=$ $10]$, hippocampal dentate gyrus dysgenesis $[n=7]$, hippocampal sclerosis $[\mathrm{n}=3]$, and gliosis $[\mathrm{n}=3]$ ). Of note, microdissected regions did not necessarily contain observed
FCD because it may have been present in other brain regions. Similarly, neuropathology was unrelated to SUDEP status (FCD in 50\% of patients with SUDEP vs $28.6 \%$ of patients with non-SUDEP epilepsy, Fisher exact test, $p=0.4216$ ).

There were no significant differences in protein expression between patients with SUDEP and those with non-SUDEP epilepsy in any brain region (figure 3,A-C, Dryad figure e-1, A-C and table e-3, doi.org/10.5061/dryad.dfn2z3508). Furthermore, a correlation of LFQ values for all proteins showed the similarity in protein expression in comparisons of patients with SUDEP and non-SUDEP epilepsy in each brain region by a Pearson correlation $(p<0.0001)$ with the corresponding $R^{2}$ values being $\geq 0.98$ (Dryad, figure e- 1 ). Brain cell typespecific annotation was evaluated in the 2,847 identified proteins, derived from previous methods, ${ }^{26}$ with $19.8 \%$ (564 of 2,847 ) proteins having an annotation while the remaining $80.2 \%$ did not and were more ubiquitously expressed or with unknown cell type. Most (78.2\%, 502 of 564) annotated 
Figure 3 Proteomics Analyses in Hippocampus, Dentate Gyrus, and Frontal Cortex of Patients With SUDEP and Non-SUDEP Epilepsy
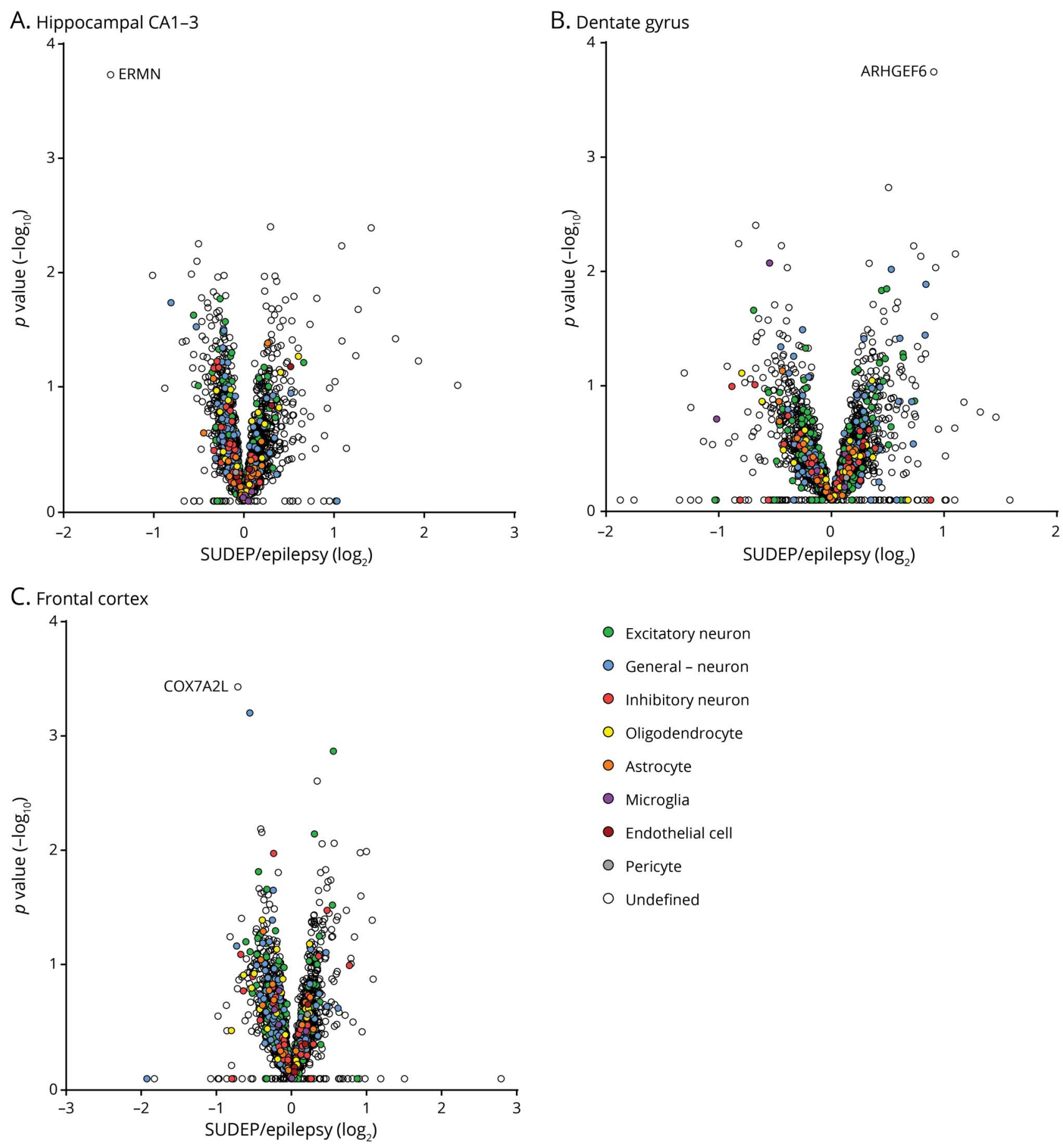

(A-C) Volcano plots indicate that there are no significantly different proteins in the hippocampal CA1-3 region, dentate gyrus, or frontal cortex of patients with sudden unexpected death in epilepsy (SUDEP) and non-SUDEP epilepsy as determined by a Student 2-tailed $t$ test with permutation correction at a 5\% false discovery rate. The top proteins with the lowest $p$ values in each brain region are noted. Cell type-specific protein annotation is included, with the most predominant listed in decreasing order in the legend. Proteins annotated general-neuron have both excitatory and inhibitory neuron annotations.

proteins were generally neuronal, with excitatory neuron proteins predominating $(48.1 \%, 271$ of 564$)$ (figure 3 , A-C, Dryad table e-3). Some proteins showed a trend for altered expression in patients with SUDEP $(p<0.01$; Dryad tables e-1 and e-2), but these were not statistically significant at a $5 \%$
FDR. Several of these protein changes have been reported in epilepsy animal models and patients without epilepsy or include proteins encoded by genes in which mutations have been previously linked to epilepsy. Yet, none of the proteins trending for altered expression in this study (Dryad tables e-1 
and 3-2) have been previously linked to SUDEP pathogenesis. ERMN had the strongest trend for difference in SUDEP with a 2.8-fold decrease in the hippocampal CA1-3 region when patients with SUDEP and patients with non-SUDEP epilepsy were compared by MS (Dryad figure e-2A). Furthermore, ERMN was detected in more patients with non-SUDEP epilepsy than patients with SUDEP by MS, indicating lower abundance of this protein in SUDEP. Validation of the quantitative MS findings with semiquantification of immunohistochemistry (Dryad figure e-2B) also showed a decrease of ERMN in patients with SUDEP with a 1.3-fold change but was not significant (Student unpaired $t$ test, $p=0.4871$ ). Because ERMN may play a role in myelinogenesis and myelin maintenance, we reviewed the mature oligodendrocyte marker myelin basic protein (MBP) but found no difference between patients with SUDEP and those with non-SUDEP epilepsy in the hippocampal CA1-3 region by MS (Dryad figure $\mathrm{e}-2 \mathrm{C}$ ).

\section{Analysis of RNAseq and Small RNAseq in Patients With Low and High Risk of SUDEP}

To determine whether there is a pathologic difference in patients with epilepsy of low (PGES $<50$ seconds, $\mathrm{n}=6$ ) and high (PGES $\geq 50$ seconds, $\mathrm{n}=8$ ) risk of SUDEP, RNAseq and small RNAseq analyses were performed on resected surgical frozen hippocampal and temporal cortex tissue. Patient histories are summarized in table 2 and figure 4A. A t-distributed stochastic neighbor embedding plot revealed that anatomic region rather than PGES segregated patients (figure 4B). A differential expression analysis comparing the hippocampus of patients at low and high risk of SUDEP identified 55 differentially expressed genes: 11 were decreased and 44 were increased in patients at high risk for SUDEP (figure 4C and Dryad table e-4, doi.org/10.5061/dryad.dfn2z3508). Brain cell type-specific annotation was evaluated in the 55 differentially expressed genes in the hippocampus, derived from previous methods, ${ }^{26}$ with $14.5 \%$ (8 of 55) of genes having a cell type-specific annotation: 4 generally neuronal, 3 excitatory neuron, and 1 inhibitory neuron. The dominant transcripts for the differentially expressed genes in hippocampus were as follows: 37 protein-coding, 15 long noncoding RNAs (lncRNAs), and 3 awaiting confirmation (figure 4D). A Reactome pathway analysis on the 55 significant genes in the hippocampus did not reveal a significant association with any signaling pathways. Several of these genes have been associated with epilepsy human disease and have been studied in animal models; however, none of the genes in table 3 have been linked to SUDEP pathogenesis. The most significantly decreased protein-coding gene in the high-risk SUDEP patients, GFRA1, was validated by real-time quantitative PCR (table 3 and Dryad figure S3). In accordance with the RNAseq analysis, GFRA1 was decreased 1.7-fold in the patients at high risk for SUDEP (Mann-Whitney $U$ test, $p=0.0121$ ). In the temporal cortex, 1 protein-coding gene (SLC6A5) with an undefined cell type annotation was significantly decreased in the patients at high risk for SUDEP, within this small group of patients (figure 4E and Dryad table e-5). No genes were differentially expressed in the small RNAseq analyses in the hippocampus and temporal cortex (Dryad tables e-6 and e-7).

\section{Comparison of SUDEP Proteome to High-Risk SUDEP Transcriptome}

Comparing the 37 differentially expressed protein-coding genes in the RNAseq analyses to the proteomics analyses, only 4 (GRM2, ERC2, CRTC1, AHNAK2) were detected in the proteomics analyses. Two (GRM2, ERC2) were detected in most patients in the hippocampal CA1-3 region but showed no trend in differential expression for patients with SUDEP compared to those with non-SUDEP epilepsy in the proteome. Additional analysis on the fold change of proteins in the hippocampus with a value of $p<0.05$ (before the FDR at $5 \%, \mathrm{n}=83$ proteins) that match RNA gene identifications ( $\mathrm{n}$ $=83$ gene identifications) do not show a significant correlation $\left(p=0.3510, R^{2}=0.01075\right.$, Pearson correlation).

\section{Discussion}

Our study compared patients with SUDEP or at high risk for SUDEP to controls with epilepsy and revealed no differentially expressed proteins in the hippocampus and frontal cortex and limited transcriptomic changes in the hippocampus and temporal cortex. Thus, the proteome in SUDEP and transcriptome in high-risk SUDEP largely reflects those in other patients with epilepsy, consistent with the diverse spectrum of syndromes and severities associated with SUDEP. ${ }^{2}$ In the hippocampus, the few differentially expressed genes identified in high-risk SUDEP included a high proportion of lncRNAs (15 of 55, 27\%). Given that we detect robust proteome ${ }^{18}$ and transcriptome ${ }^{17}$ differences in the hippocampus and cortex with similar group sizes for patients with epilepsy and controls without epilepsy, our data in this study suggest that these brain regions are not especially or uniquely affected in SUDEP.

To validate the label-free quantitative MS findings, immunohistochemistry was used to confirm changes in ERMN expression because this protein had the strongest trend for difference in SUDEP. Immunohistochemistry results corroborated a trend in a decreased fold change of ERMN in the hippocampal CA1-3 region of patients with SUDEP compared to those with non-SUDEP epilepsy, although this similarly was not significant. Furthermore, ERMN was not significantly altered in the current RNAseq study or in our previous proteomics analyses between patients with nonSUDEP epilepsy and controls. ${ }^{18}$ However, in our previous RNAseq study between patients with MTLE and controls without epilepsy, ERMN was decreased ${ }^{17}$ and is reportedly decreased in a murine model of status epilepticus. ${ }^{29}$ Expressed by oligodendrocytes, ERMN regulates cytoskeleton arrangement during myelinogenesis and myelin sheath maintenance. ${ }^{30}$ Myelin damage may occur after prolonged seizures, and its loss may promote further seizure activity. ${ }^{31} \mathrm{We}$ found that the mature oligodendrocyte marker MBP is decreased in 
A

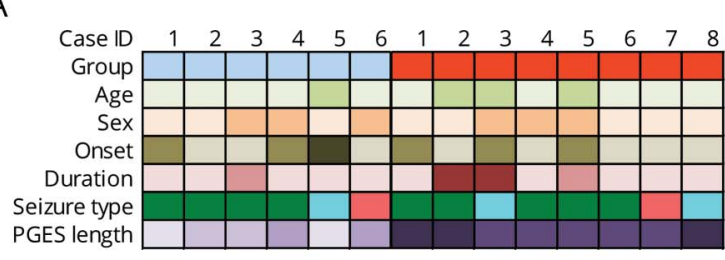

B

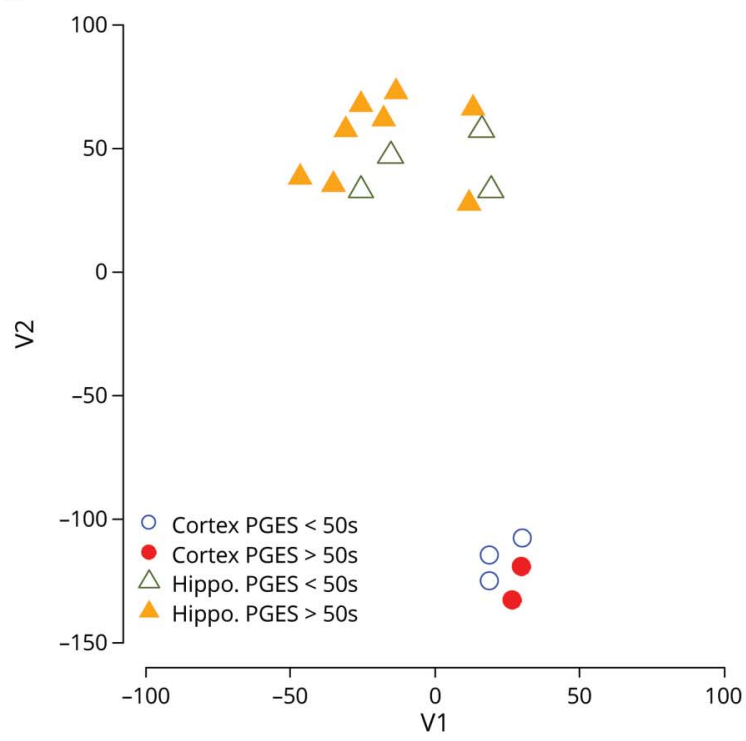

D

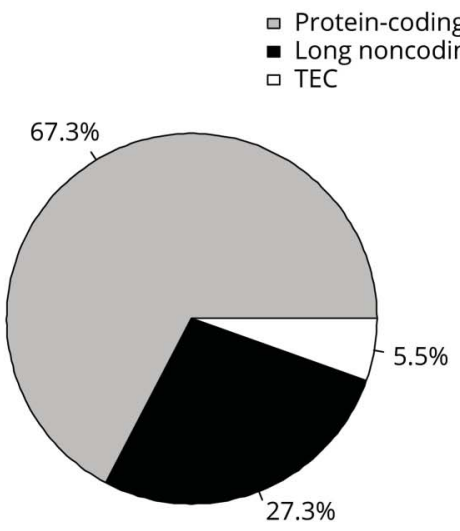

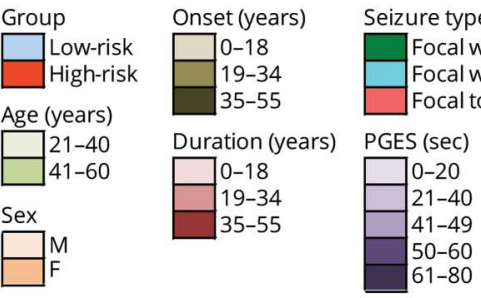

C. Hippocampus

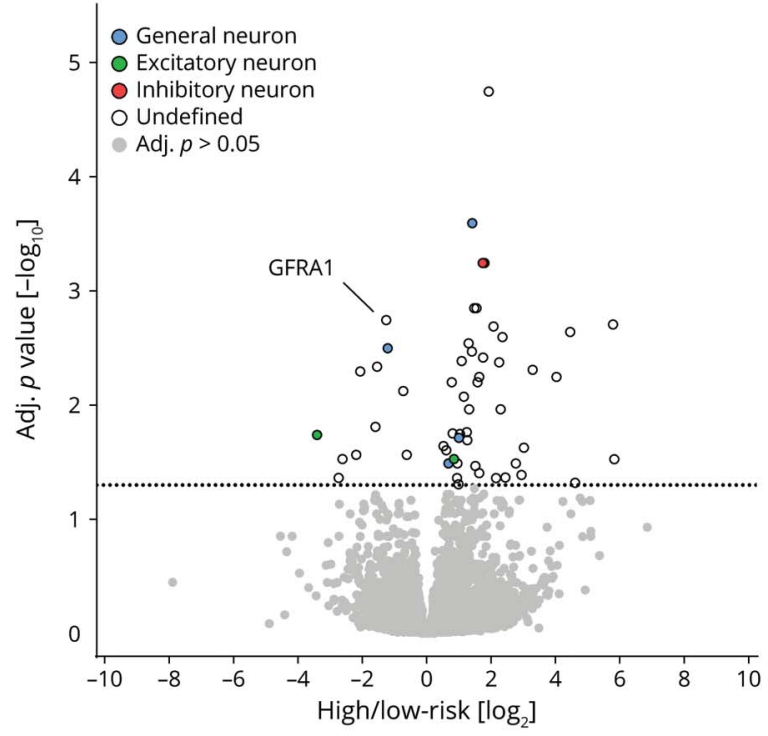

E. Temporal cortex

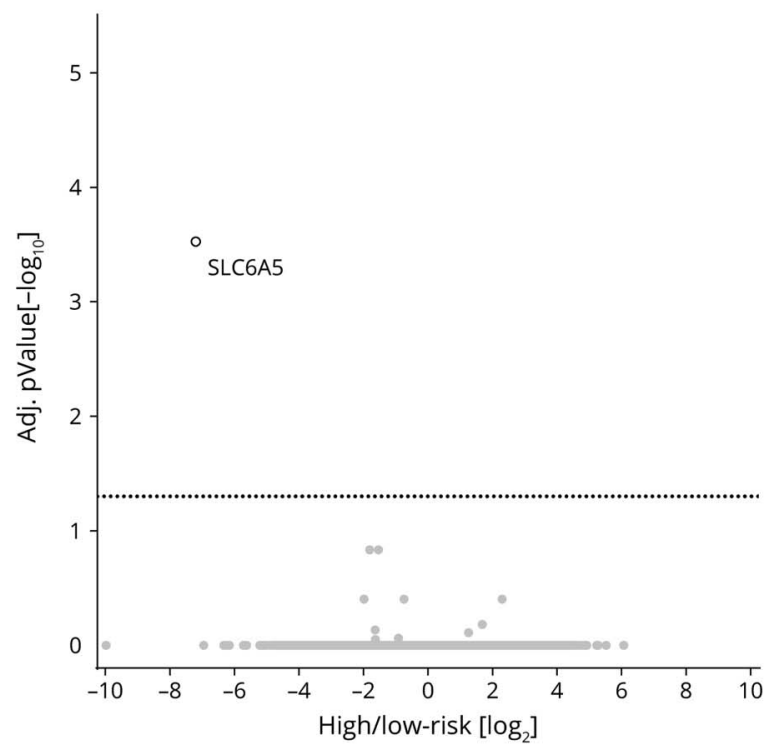

(A) Patient history is summarized for patients at low and high risk for sudden unexpected death in epilepsy (SUDEP). (B) The t-distributed stochastic neighbor embedding plot of RNA sequencing (RNAseq) data shows separation by brain region rather than SUDEP risk status. (C) Volcano plot shows the results of differential expression analysis of the hippocampus from patients at low risk $(n=4)$ and high risk $(n=8)$ of SUDEP. Eleven genes were decreased and 44 genes were increased in hippocampus of patients at high risk of SUDEP. The Wald test identified differentially expressed genes using a Benjamini-Hochbergadjusted value of $p<0.05$ for significance. Cell type-specific gene annotation is included, with the most predominant listed in decreasing order in the legend. Genes annotated general-neuron have both excitatory and inhibitory neuron annotations. (D) Biotypes of differentially expressed genes are depicted in the hippocampus for patients at high risk for SUDEP compared to those at low risk of SUDEP. Of the 55 differentially expressed genes, $67.3 \%$ were protein-coding genes, $27.3 \%$ were long noncoding RNAs, and $5.5 \%$ are yet to be experimentally confirmed (TEC). (E) Volcano plot shows the results of differential expression analysis in the temporal cortex from patients at low risk $(n=2)$ and high risk $(n=3)$ of SUDEP. One gene was decreased and no genes were increased in the temporal cortex. The Wald test identified differentially expressed genes using a Benjamini-Hochberg-adjusted value of $p<0.05$ for significance. 
Table 3 Top 20 Significant Protein-Coding Genes in Hippocampus of Patients at High vs Low Risk of SUDEP

\begin{tabular}{|c|c|c|c|c|c|c|}
\hline Ensembl gene ID & Gene ID & Gene name & $\begin{array}{l}\text { UniProt } \\
\text { ID }\end{array}$ & $\begin{array}{l}\text { Adjusted } \\
p \text { value }\end{array}$ & $\begin{array}{l}\text { Fold } \\
\text { change }\end{array}$ & Related references \\
\hline \multicolumn{7}{|l|}{ Increased } \\
\hline ENSG00000164082.14 & GRM2 & $\begin{array}{l}\text { Glutamate } \\
\text { metabotropic } \\
\text { receptor } 2\end{array}$ & Q14416 & 0.00002 & 3.80 & $\begin{array}{l}\text { Increased protein in epilepsy }{ }^{18} ; \text { GRM2 knockout } \\
\text { mice are NMDA toxicity resistant and thus } \\
\text { GRM2 activation may be damaging to neurons } \\
\text { exposed to toxic insults }{ }^{45} \text {; decreased transcript } \\
\text { in MTLE with sclerosis }{ }^{46} \text { and in models of status } \\
\text { epilepticus }^{47,48}\end{array}$ \\
\hline ENSG00000137766.16 & UNC13C & Unc-13 Homolog C & Q8NB66 & 0.00026 & 2.67 & $\begin{array}{l}\text { Increased transcript in status epilepticus } \\
\text { murine model }\end{array}$ \\
\hline ENSG00000082293.12 & COL19A1 & $\begin{array}{l}\text { Collagen type XIX } \\
\text { alpha } 1 \text { chain }\end{array}$ & Q14993 & 0.00057 & 3.33 & \\
\hline ENSG00000164112.12 & TMEM155 & $\begin{array}{l}\text { Transmembrane } \\
\text { protein } 155\end{array}$ & Q4W5P6 & 0.00057 & 3.47 & \\
\hline ENSG00000152784.15 & PRDM8 & PR/SET domain 8 & Q9NQV8 & 0.00142 & 2.79 & $\begin{array}{l}\text { Gain-of-function mutation results in myoclonus } \\
\text { epilepsy with Lafora bodies }\end{array}$ \\
\hline ENSG00000027001.9 & MIPEP & $\begin{array}{l}\text { Mitochondrial } \\
\text { intermediate } \\
\text { peptidase }\end{array}$ & Q99797 & 0.00142 & 2.92 & \\
\hline ENSG00000102683.7 & $S G C G$ & Sarcoglycan gamma & Q13326 & 0.00229 & 22.01 & \\
\hline ENSG00000033867.16 & SLC4A7 & $\begin{array}{l}\text { Solute carrier family } \\
4 \text { member } 7\end{array}$ & Q9Y6M7 & 0.00287 & 2.47 & $\begin{array}{l}\text { Increased transcript in status epilepticus } \\
\text { murine mode }\left.\right|^{29}\end{array}$ \\
\hline ENSG00000164638.10 & SLC29A4 & $\begin{array}{l}\text { Solute carrier family } \\
29 \text { member } 4\end{array}$ & Q7RTT9 & 0.00412 & 2.12 & \\
\hline ENSG00000171126.7 & KCNG3 & $\begin{array}{l}\text { Potassium voltage- } \\
\text { gated channel } \\
\text { modifier subfamily G } \\
\text { member } 3\end{array}$ & Q8TAE7 & 0.00566 & 3.09 & \\
\hline
\end{tabular}

\begin{tabular}{|c|c|c|c|c|c|c|}
\hline \multicolumn{7}{|l|}{ Decreased } \\
\hline \multirow[t]{2}{*}{ ENSG00000151892.14 } & GFRA1 & $\begin{array}{l}\text { GDNF family receptor } \\
\text { alpha-1 }\end{array}$ & P56159 & 0.00180 & 2.39 & \multirow[t]{2}{*}{$\begin{array}{l}\text { Localized GDNF release in animal models of } \\
\text { epilepsy suppresses seizure activity }{ }^{36,50}\end{array}$} \\
\hline & SORCS1 & $\begin{array}{l}\text { Sortilin related VPS10 } \\
\text { domain containing } \\
\text { receptor } 1\end{array}$ & Q8WY21 & 0.00318 & 2.32 & \\
\hline ENSG00000146070.16 & PLA2G7 & $\begin{array}{l}\text { Phospholipase A2 } \\
\text { group VII }\end{array}$ & Q13093 & 0.00461 & 2.91 & $\begin{array}{l}\text { Decreased transcript in status epilepticus } \\
\text { murine mode }{ }^{29}\end{array}$ \\
\hline ENSG00000005981.12 & ASB4 & $\begin{array}{l}\text { Ankyrin repeat and } \\
\text { SOCS box containing } \\
4\end{array}$ & Q9Y574 & 0.00507 & 4.18 & \\
\hline ENSG00000185567.6 & AHNAK2 & $\begin{array}{l}\text { AHNAK } \\
\text { nucleoprotein } 2\end{array}$ & Q8IVF2 & 0.00752 & 1.65 & \\
\hline ENSG00000140557.11 & STSSIA2 & $\begin{array}{l}\text { Alpha-2,8- } \\
\text { sialyltransferase 8B }\end{array}$ & Q92186 & 0.01550 & 3.02 & \\
\hline ENSG00000152595.16 & MEPE & $\begin{array}{l}\text { Matrix extracellular } \\
\text { phosphoglycoprotein }\end{array}$ & Q9NQ76 & 0.02729 & 4.56 & \\
\hline ENSG00000177106.14 & EPS8L2 & EPS8 like 2 & Q9H6S3 & 0.02729 & 1.54 & \\
\hline ENSG00000189127.7 & $A N K R D 34 B$ & $\begin{array}{l}\text { Ankyrin repeat } \\
\text { domain } 34 \mathrm{~B}\end{array}$ & A5PLL1 & 0.02963 & 6.12 & \\
\hline ENSG00000224982.3 & TMEM233 & $\begin{array}{l}\text { Transmembrane } \\
\text { protein } 233\end{array}$ & B4DJY2 & 0.04331 & 6.65 & \\
\hline
\end{tabular}

Abbreviations: GDNF = glial cell-derived neurotrophic factor; ID = identification; MTLE = mesial temporal lobe epilepsy; SUDEP = sudden unexplained death in epilepsy. 
patients with epilepsy compared with controls without epilepsy, ${ }^{18}$ and it is decreased in the hippocampus of an animal model of epilepsy. ${ }^{32}$ However, we found no further decrease in MBP expression in patients with SUDEP or those at high risk of SUDEP compared to controls in this study, nor was $M B P$ different in our recent RNAseq analysis between patients with MTLE and controls without epilepsy. ${ }^{17}$ Overall, ERMN is significantly decreased in those with surgical MTLE vs controls without epilepsy at the transcriptomic level ${ }^{17}$ and trending to decrease in protein expression of SUDEP vs nonSUDEP epilepsy, indicating that ERMN may be decreased in response to the elevated seizure activity that may be seen in refractory epilepsy that requires surgery and in some patients with SUDEP. The effect on myelination, as measured by MBP, is apparent only in these patients for protein expression rather than gene expression in patients with epilepsy vs controls without epilepsy with no further decrease in SUDEP. Thus, further investigation should assess the potential role of ERMN in epilepsy and SUDEP and whether reduced ERMN may reflect the severity of pathology resulting from seizure burden in some patients with SUDEP.

The RNAseq and small RNAseq analyses showed moderate changes in the hippocampus and minimal differences in the temporal cortex in patients with MTLE at high risk compared to low risk for SUDEP. Fifteen of 55 differentially expressed genes in the hippocampus were IncRNAs. LncRNAs are an understudied transcriptomic component implicated in many neurologic disorders, ${ }^{33}$ but few studies have been done regarding their role in epilepsy or SUDEP. ${ }^{34}$ Among the protein-coding genes differentially expressed in the hippocampus, GFRA1 was the most decreased. GDNF binds to GFRA1 and plays a role in neuronal survival and differentiation, including that of GABAergic interneurons. ${ }^{35}$ Localized release of GDNF in the hippocampus of an animal model of epilepsy suppresses seizure activity. ${ }^{36}$ Thus, decreased GFRA1 may reflect a change in cell survival or result in reduced GDNF-mediated seizure suppression in patients at high risk for SUDEP. Of the top 20 differentially expressed genes (table 3), sarcoglycan gamma (SGCG) had the largest change at a 22.0-fold increase (adjusted $p=0.0023$ ) in the patients at high risk for SUDEP. SGCG is expressed in the cerebrovascular system and may localize to vascular smooth muscle cells, potentially involved in membrane contractility, stabilization, and signaling in the associated dystrophin complex affecting neurovascular coupling. ${ }^{37}$ Its neural role is unknown, but aberrant cerebrovascular organization occurs in MTLE. ${ }^{38}$ Additional studies are needed to determine how the altered levels of some protein-coding genes and lncRNAs we identified may affect mechanisms related to SUDEP risk.

Protein expression in the brain has rarely been studied in human SUDEP. Hippocampal HSP70-positive neurons are reportedly increased in postmortem patients with SUDEP compared to patients with non-SUDEP epilepsy but are similar to patients with surgical epilepsy, suggesting this is likely related to antemortem neuronal injury perhaps due to a terminal seizure in patients with SUDEP. ${ }^{39}$ HSP70 expression was similar in both the proteomic and RNAseq analyses among our patients. Another immunohistochemistry study found few differences in the hippocampus, amygdala, and medulla of postmortem SUDEP compared to non-SUDEP epilepsy and controls without epilepsy with minimal significant changes reported for several markers of inflammation (CD163, HLA-DR, GFAP), compromised blood-brain barrier (immunoglobulin $\mathrm{G}$, albumin), and hypoxia-inducible factor- $1 \alpha$, a transcriptional regulator of cellular responses to hypoxia. ${ }^{12} \mathrm{We}$ found increased GFAP in the hippocampus of 3 patients with epilepsy ( 3 of 26, 11.5\%); 2 had gliosis independently of SUDEP status. GFAP was not increased in most patients with non-SUDEP epilepsy compared to controls without epilepsy, ${ }^{18}$ but it was increased in the hippocampus of 1 ( 1 of $14,7.1 \%)$ patient with epilepsy with hippocampal gliosis. Increased GFAP occurs in some patients with epilepsy and after prolonged seizures in rodent models. ${ }^{40}$ Furthermore, GFAP was not altered in patients with MTLE with high risk of SUDEP in the current RNAseq analysis, but this gene was significantly increased in the hippocampus of patients with MTLE compared to controls without epilepsy. ${ }^{17}$

Our study had some limitations. The LCM-derived label-free quantitative MS allows detection of localized protein changes that would not be possible with bulk homogenate; however, this technique detects a lower quantity of membrane proteins that are relatively insoluble with this method. Thus, we may not detect differential expression of some membrane proteins, although downstream signaling pathways reflecting their functional activity may be identified. Additional limitations include the heterogeneity of epilepsies, seizure types, and neuropathology due to available patients, further reinforcing the importance of banking various brain tissue samples from patients with SUDEP. Our study was powered to identify proteomic differences across the representative SUDEP group rather than epilepsy subgroups. Potential pathogenic gene variants were not assessed in our patients. Our proteomics analyses were based on NASR referrals, skewed by major referral sources: the San Diego Medical Examiner Office (mainly White and Hispanic patients at low socioeconomic levels) and direct referrals (mainly White patients at high socioeconomic levels). For the RNAseq analyses, surgical patients had treatment-resistant MTLE. PGES duration as a biomarker of SUDEP risk has not been validated and can vary within the same patient for different seizures, and the number of video EEG-recorded GTCS in each patient was limited. ${ }^{4,41,42}$ Thus, group differences may reflect sampling bias. Furthermore, the number of patients used for the RNAseq temporal cortex analyses was low. Last, further investigation is needed in brain regions implicated in SUDEP, including the brainstem, because it modulates autonomic functions, and it has been suggested that seizure-induced postictal depression of arousal, respiratory, and cardiac function may occur in SUDEP. ${ }^{43,44}$

In contrast to the robust differences we found in proteomic and RNAseq analyses between patients with epilepsy and 
those without epilepsy, ${ }^{17,18}$ no differences were detected in the proteomic analyses of autopsy tissue from patients with SUDEP and those with non-SUDEP epilepsy, and limited transcriptomic differences were seen in comparisons of surgical tissue from patients at low and high risk for SUDEP in the brain regions analyzed, consistent with the diverse epilepsy syndromes and comorbid conditions associated with SUDEP and indicating that epilepsy subtypes and additional brain regions should be examined further.

\section{Acknowledgment}

The authors thank the participating families and clinicians for their involvement with the NASR.

\section{Study Funding}

National Institute of Neurological Disorders and Stroke UO1 NS090415 05 Center for SUDEP Research: The Neuropathology of SUDEP, Finding A Cure for Epilepsy and Seizures (FACES), National Institute of Aging P30AG066512, European Union's Seventh Framework Program (FP7/ 2007-2013) under grant agreement 602102 (EPITARGET; E.A.v.V., E.A.), and the Top Sector Life Sciences \& Health via a PPP Allowance made available to the Dutch Epilepsy Foundation to stimulate public-private partnerships (E.A.v.V., E.A.). This work was supported by funding from the Bluesand Foundation to E.D. and Philippe Chatrier Foundation to G.P. The proteomics work was in part supported by the NYU School of Medicine and a shared instrumentation grant from the NIH, 1S10OD010582-01A1, for the purchase of an Orbitrap Fusion Lumos.

\section{Disclosure}

The authors declare that they have no competing interests. Go to Neurology.org/N for full disclosures.

\section{Publication History}

Received by Neurology August 11, 2020. Accepted in final form February 26, 2021.

\begin{tabular}{lll}
\multicolumn{2}{l}{ Appendix Authors } \\
\hline Name & Location & Contribution \\
\hline $\begin{array}{l}\text { Dominique F. } \\
\text { Leitner, PhD }\end{array}$ & $\begin{array}{l}\text { NYU School of } \\
\text { Medicine }\end{array}$ & $\begin{array}{l}\text { Data collection and analysis, } \\
\text { drafting and revision of } \\
\text { manuscript }\end{array}$ \\
\hline $\begin{array}{l}\text { James D. Mills, } \\
\text { PhD }\end{array}$ & Amsterdam UMC & $\begin{array}{l}\text { Data collection and analysis, } \\
\text { drafting and revision of } \\
\text { manuscript }\end{array}$ \\
\hline $\begin{array}{l}\text { Geoffrey Pires, } \\
\text { MS }\end{array}$ & NYU School of & $\begin{array}{l}\text { Data collection and analysis, } \\
\text { drafting and revision of } \\
\text { manuscript }\end{array}$ \\
\hline $\begin{array}{l}\text { Arline Faustin, } \\
\text { MD }\end{array}$ & $\begin{array}{l}\text { NYU School of } \\
\text { Medicine }\end{array}$ & $\begin{array}{l}\text { Clinical data collection, } \\
\text { drafting and revision of } \\
\text { manuscript }\end{array}$ \\
\hline
\end{tabular}

Appendix (continued)

\begin{tabular}{|c|c|c|}
\hline Name & Location & Contribution \\
\hline $\begin{array}{l}\text { Eleanor } \\
\text { Drummond, } \\
\text { PhD }\end{array}$ & University of Sydney & $\begin{array}{l}\text { Data collection and analysis, } \\
\text { drafting and revision of } \\
\text { manuscript }\end{array}$ \\
\hline $\begin{array}{l}\text { Evgeny } \\
\text { Kanshin, PhD }\end{array}$ & $\begin{array}{l}\text { NYU School of } \\
\text { Medicine }\end{array}$ & $\begin{array}{l}\text { Data collection and analysis, } \\
\text { drafting and revision of } \\
\text { manuscript }\end{array}$ \\
\hline $\begin{array}{l}\text { Shruti Nayak, } \\
\text { MS }\end{array}$ & $\begin{array}{l}\text { NYU School of } \\
\text { Medicine }\end{array}$ & Data collection and analysis \\
\hline $\begin{array}{l}\text { Manor } \\
\text { Askenazi, PhD }\end{array}$ & Biomedical Hosting LLC & $\begin{array}{l}\text { Data analysis, drafting and } \\
\text { revision of manuscript }\end{array}$ \\
\hline $\begin{array}{l}\text { Chloe } \\
\text { Verducci, BA }\end{array}$ & $\begin{array}{l}\text { NYU School of } \\
\text { Medicine }\end{array}$ & $\begin{array}{l}\text { Clinical data collection, } \\
\text { revision of manuscript }\end{array}$ \\
\hline $\begin{array}{l}\text { Bei Jun Chen, } \\
\text { PhD }\end{array}$ & $\begin{array}{l}\text { University of New } \\
\text { South Wales }\end{array}$ & Data analysis \\
\hline $\begin{array}{l}\text { Michael Janitz, } \\
\text { PhD }\end{array}$ & $\begin{array}{l}\text { University of New } \\
\text { South Wales }\end{array}$ & Data analysis \\
\hline $\begin{array}{l}\text { Jasper J. Anink, } \\
\text { BSc }\end{array}$ & Amsterdam UMC & Clinical data collection \\
\hline $\begin{array}{l}\text { Johannes C. } \\
\text { Baayen, MD }\end{array}$ & Amsterdam UMC & Clinical data collection \\
\hline $\begin{array}{l}\text { Sander Idema, } \\
\text { MD, PhD }\end{array}$ & Amsterdam UMC & Clinical data collection \\
\hline $\begin{array}{l}\text { Erwin A. van } \\
\text { Vliet, PhD }\end{array}$ & Amsterdam UMC & Data collection \\
\hline $\begin{array}{l}\text { Sasha Devore, } \\
\text { PhD }\end{array}$ & $\begin{array}{l}\text { NYU School of } \\
\text { Medicine }\end{array}$ & Revision of manuscript \\
\hline $\begin{array}{l}\text { Daniel } \\
\text { Friedman, MD, } \\
\text { MSc }\end{array}$ & $\begin{array}{l}\text { NYU School of } \\
\text { Medicine }\end{array}$ & $\begin{array}{l}\text { Clinical data collection, } \\
\text { drafting and revision of } \\
\text { manuscript }\end{array}$ \\
\hline $\begin{array}{l}\text { Beate Diehl, } \\
\text { MD, PhD }\end{array}$ & $\begin{array}{l}\text { University College } \\
\text { London }\end{array}$ & Clinical data collection \\
\hline $\begin{array}{l}\text { Catherine } \\
\text { Scott, MPhil }\end{array}$ & $\begin{array}{l}\text { University College } \\
\text { London }\end{array}$ & Clinical data collection \\
\hline $\begin{array}{l}\text { Roland Thijs, } \\
\text { MD, PhD }\end{array}$ & $\begin{array}{l}\text { Stichting Epilepsie } \\
\text { Instellingen Nederland }\end{array}$ & Clinical data collection \\
\hline $\begin{array}{l}\text { Thomas } \\
\text { Wisniewski, } \\
\text { MD }\end{array}$ & $\begin{array}{l}\text { NYU School of } \\
\text { Medicine }\end{array}$ & $\begin{array}{l}\text { Clinical data collection, } \\
\text { drafting and revision of } \\
\text { manuscript }\end{array}$ \\
\hline $\begin{array}{l}\text { Beatrix } \\
\text { Ueberheide, } \\
\text { PhD }\end{array}$ & $\begin{array}{l}\text { NYU School of } \\
\text { Medicine }\end{array}$ & $\begin{array}{l}\text { Data collection and analysis, } \\
\text { drafting and revision of } \\
\text { manuscript }\end{array}$ \\
\hline $\begin{array}{l}\text { Maria Thom, } \\
\text { MD }\end{array}$ & $\begin{array}{l}\text { University College } \\
\text { London }\end{array}$ & $\begin{array}{l}\text { Clinical data collection, } \\
\text { drafting and revision of } \\
\text { manuscript }\end{array}$ \\
\hline $\begin{array}{l}\text { Eleonora } \\
\text { Aronica, MD, } \\
\text { PhD }\end{array}$ & $\begin{array}{l}\text { Stichting Epilepsie } \\
\text { Instellingen Nederland }\end{array}$ & $\begin{array}{l}\text { Design and conceptualized } \\
\text { study, clinical data } \\
\text { collection, drafting } \\
\text { and revision of } \\
\text { manuscript }\end{array}$ \\
\hline $\begin{array}{l}\text { Orrin } \\
\text { Devinsky, MD }\end{array}$ & $\begin{array}{l}\text { NYU School of } \\
\text { Medicine }\end{array}$ & $\begin{array}{l}\text { Design and conceptualized } \\
\text { study, clinical data } \\
\text { collection, drafting and } \\
\text { revision of } \\
\text { manuscript }\end{array}$ \\
\hline
\end{tabular}




\section{References}

1. Devinsky O, Hesdorffer DC, Thurman DJ, Lhatoo S, Richerson G. Sudden unexpected death in epilepsy: epidemiology, mechanisms, and prevention. Lancet Neurol. 2016;15(10):1075-1088.

2. Verducci C, Hussain F, Donner E, et al. SUDEP in the North American SUDEP Registry: the full spectrum of epilepsies. Neurology. 2019;93(3):e227-e236.

3. Thom M, Michalak Z, Wright G, et al. Audit of practice in sudden unexpected death in epilepsy (SUDEP) post mortems and neuropathological findings. Neuropathol Appl Neurobiol. 2016;42(5):463-476

4. Kang JY, Rabiei AH, Myint L, Nei M. Equivocal significance of post-ictal generalized EEG suppression as a marker of SUDEP risk. Seizure. 2017;48:28-32.

5. Myers CT, Mefford HC. Advancing epilepsy genetics in the genomic era. Genome Med. 2015;7:91.

6. Friedman D, Kannan K, Faustin A, et al. Cardiac arrhythmia and neuroexcitability gene variants in resected brain tissue from patients with sudden unexpected death in epilepsy (SUDEP). NPJ Genom Med. 2018;3:9.

7. Wang J, Lin ZJ, Liu L, et al. Epilepsy-associated genes. Seizure. 2017;44:11-20.

8. Zhang H, Zhao H, Zeng C, et al. Optogenetic activation of 5-HT neurons in the dorsal raphe suppresses seizure-induced respiratory arrest and produces anticonvulsant effect in the DBA/1 mouse SUDEP model. Neurobiol Dis. 2018;110:47-58.

9. Zhang P, Zhang L, Li Y, et al. Quantitative proteomic analysis to identify differentially expressed proteins in myocardium of epilepsy using iTRAQ coupled with nano-LCMS/MS. J Proteome Res. 2018;17(1):305-314

10. Kalume F, Westenbroek RE, Cheah CS, et al. Sudden unexpected death in a mouse model of Dravet syndrome. J Clin Invest. 2013;123(4):1798-1808.

11. Thom M, Boldrini M, Bundock E, Sheppard MN, Devinsky O. Review: the past, present and future challenges in epilepsy-related and sudden deaths and biobanking. Neuropathol Appl Neurobiol 2018;44(1):32-55.

12. Michalak Z, Obari D, Ellis M, Thom M, Sisodiya SM. Neuropathology of SUDEP: role of inflammation, blood-brain barrier impairment, and hypoxia. Neurology. 2017; 88(6):551-561.

13. Aronica E, Mühlebner A. Neuropathology of epilepsy. Handb Clin Neurol. 2017;145: 193-216.

14. Mendonça CF, Kuras M, Nogueira FCS, et al. Proteomic signatures of brain regions affected by tau pathology in early and late stages of Alzheimer's disease. Neurobiol Dis. 2019;130:104509.

15. Johnson ECB, Dammer EB, Duong DM, et al. Deep proteomic network analysis of Alzheimer's disease brain reveals alterations in RNA binding proteins and RNA splicing associated with disease. Mol Neurodegener. 2018;13(1):52.

16. Xu J, Patassini S, Rustogi N, et al. Regional protein expression in human Alzheimer's brain correlates with disease severity. Commun Biol. 2019;2:43.

17. Mills JD, van Vliet EA, Chen BJ, et al. Coding and non-coding transcriptome of mesial temporal lobe epilepsy: critical role of small non-coding RNAs. Neurobiol Dis. 2020; 134:104612.

18. Pires G, Leitner D, Drummond E, et al. Proteomic differences in the hippocampus and cortex of epilepsy brain tissue. Brain Communications. 2021;doi:10.1093/braincomms/fcab021

19. Kinney HC, Poduri AH, Cryan JB, et al. Hippocampal formation maldevelopment and sudden unexpected death across the pediatric age spectrum. J Neuropathol Exp Neurol. 2016;75(10):981-997.

20. Drummond ES, Nayak S, Ueberheide B, Wisniewski T. Proteomic analysis of neurons microdissected from formalin-fixed, paraffin-embedded Alzheimer's disease brain tissue. Sci Rep. 2015;5:15456.

21. Drummond E, Nayak S, Ueberheide B, Wisniewski T. Localized proteomics of individual neurons isolated from formalin-fixed, paraffin-embedded tissue sections using laser capture microdissection. Acta Neuropathol. 2017:289-301.

22. Drummond E, Pires G, MacMurray C, et al. Phosphorylated tau interactome in the human Alzheimer's disease brain. Brain. 2020;143:2803-2817.

23. Cox J, Mann M. MaxQuant enables high peptide identification rates, individualized p.p.b.-range mass accuracies and proteome-wide protein quantification. Nat Biotechnol. 2008;26(12):1367-1372.

24. Cox J, Hein MY, Luber CA, Paron I, Nagaraj N, Mann M. Accurate proteome-wide label-free quantification by delayed normalization and maximal peptide ratio extraction, termed MaxLFQ. Mol Cel Proteomics. 2014;13(9):2513-2526.

25. Tyanova S, Temu T, Sinitcyn P, et al. The Perseus computational platform for comprehensive analysis of (prote)omics data. Nat Methods. 2016;13(9):731-740.
26. Lake BB, Chen S, Sos BC, et al. Integrative single-cell analysis of transcriptional and epigenetic states in the human adult brain. Nat Biotechnol. 2018;36(1):70-80.

27. Drummond E, Nayak S, Faustin A, et al. Proteomic differences in amyloid plaques in rapidly progressive and sporadic Alzheimer's disease. Acta Neuropathol. 2017;133(6) 933-954.

28. Ye J, Coulouris G, Zaretskaya I, Cutcutache I, Rozen S, Madden TL. Primer-BLAST: tool to design target-specific primers for polymerase chain reaction. BMC Bioinformatics. 2012;13:134.

29. Hansen KF, Sakamoto K, Pelz C, Impey S, Obrietan K. Profiling status epilepticusinduced changes in hippocampal RNA expression using high-throughput RNA sequencing. Sci Rep. 2014;4:6930.

30. Brockschnieder D, Sabanay H, Riethmacher D, Peles E. Ermin, a myelinating oligodendrocyte-specific protein that regulates cell morphology. J Neurosci. 2006; 26(3):757-762.

31. Gibson EM, Geraghty AC, Monje M. Bad wrap: myelin and myelin plasticity in health and disease. Dev Neurobiol. 2018;78(2):123-135

32. Ye Y, Xiong J, Hu J, et al. Altered hippocampal myelinated fiber integrity in a lithiumpilocarpine model of temporal lobe epilepsy: a histopathological and stereological investigation. Brain Res. 2013;1522:76-87.

33. Li L, Zhuang Y, Zhao X, Li X. Long non-coding RNA in neuronal development and neurological disorders. Front Genet. 2018;9:744.

34. Villa C, Lavitrano M, Combi R. Long non-coding RNAs and related molecular pathways in the pathogenesis of epilepsy. Int J Mol Sci. 2019;20(19).

35. Canty AJ, Dietze J, Harvey M, Enomoto H, Milbrandt J, Ibáñez CF. Regionalized loss of parvalbumin interneurons in the cerebral cortex of mice with deficits in GFRalphal signaling. J Neurosci. 2009;29(34):10695-10705.

36. Kanter-Schlifke I, Fjord-Larsen L, Kusk P, Angehagen M, Wahlberg L, Kokaia M. GDNF released from encapsulated cells suppresses seizure activity in the epileptic hippocampus. Exp Neurol. 2009;216(2):413-419.

37. Boulay AC, Saubaméa B, Cisternino S, et al. The Sarcoglycan complex is expressed in the cerebrovascular system and is specifically regulated by astroglial $\mathrm{Cx} 30$ channels. Front Cel Neurosci. 2015;9:9.

38. Guelfi S, Botia JA, Thom M, et al. Transcriptomic and genetic analyses reveal potentia causal drivers for intractable partial epilepsy. Brain. 2019;142(6):1616-1630.

39. Thom M, Seetah S, Sisodiya S, Koepp M, Scaravilli F. Sudden and unexpected death in epilepsy (SUDEP): evidence of acute neuronal injury using HSP-70 and c-Jun immunohistochemistry. Neuropathol Appl Neurobiol. 2003;29(2):132-143.

40. Robel S. Astroglial scarring and seizures: a cell biological perspective on epilepsy. Neuroscientist. 2017;23(2):152-168

41. Rajakulendran S, Nashef L. Postictal generalized EEG suppression and SUDEP: review. J Clin Neurophysiol. 2015;32(1):14-20.

42. Lamberts RJ, Gaitatzis A, Sander JW, Elger CE, Surges R, Thijs RD. Postictal gen eralized EEG suppression: an inconsistent finding in people with multiple seizures. Neurology. 2013;81(14):1252-1256.

43. Mueller SG, Nei M, Bateman LM, et al. Brainstem network disruption: a pathway to sudden unexplained death in epilepsy?. Hum Brain Mapp. 2018;39(12):4820-4830.

44. Patodia S, Somani A, O'Hare M, et al. The ventrolateral medulla and medullary raphe in sudden unexpected death in epilepsy. Brain. 2018;141(6):1719-1733.

45. Corti C, Battaglia G, Molinaro G, et al. The use of knock-out mice unravels distinct roles for mGlu2 and mGlu3 metabotropic glutamate receptors in mechanisms of neurodegeneration/neuroprotection. J Neurosci. 2007;27(31):8297-8308.

46. Griffin NG, Wang Y, Hulette CM, et al. Differential gene expression in dentate granule cells in mesial temporal lobe epilepsy with and without hippocampal sclerosis. Epilepsia. 2016;57(3):376-385

47. Aronica EM, Gorter JA, Paupard MC, Grooms SY, Bennett MV, Zukin RS. Status epilepticus-induced alterations in metabotropic glutamate receptor expression in young and adult rats. J Neurosci. 1997;17(21):8588-8595.

48. Pacheco Otalora LF, Couoh J, Shigamoto R, Zarei MM, Garrido Sanabria ER. Abnormal mGluR2/3 expression in the perforant path termination zones and mossy fibers of chronically epileptic rats. Brain Res. 2006;1098(1):170-185.

49. Turnbull J, Girard JM, Lohi H, et al. Early-onset Lafora body disease. Brain. 2012; 135(pt 9):2684-2698.

50. Martin D, Miller G, Rosendahl M, Russell DA. Potent inhibitory effects of glial derived neurotrophic factor against kainic acid mediated seizures in the rat. Brain Res. 1995; 683(2):172-178 


\section{Neurology}

\section{Proteomics and Transcriptomics of the Hippocampus and Cortex in SUDEP and High-Risk SUDEP Patients}

Dominique F. Leitner, James D. Mills, Geoffrey Pires, et al.

Neurology 2021;96;e2639-e2652 Published Online before print April 28, 2021

DOI 10.1212/WNL.0000000000011999

\section{This information is current as of April 28, 2021}

\section{Updated Information \&} Services

References

Subspecialty Collections

Permissions \& Licensing

Reprints including high resolution figures, can be found at: http://n.neurology.org/content/96/21/e2639.full

This article cites 48 articles, 7 of which you can access for free at: http://n.neurology.org/content/96/21/e2639.full\#ref-list-1

This article, along with others on similar topics, appears in the following collection(s):

All Epilepsy/Seizures

http://n.neurology.org/cgi/collection/all_epilepsy_seizures Forensic neurology http://n.neurology.org/cgi/collection/forensic_neurology

Information about reproducing this article in parts (figures,tables) or in its entirety can be found online at:

http://www.neurology.org/about/about_the_journal\#permissions

Information about ordering reprints can be found online:

http://n.neurology.org/subscribers/advertise

Neurology ${ }^{\circledR}$ is the official journal of the American Academy of Neurology. Published continuously since 1951, it is now a weekly with 48 issues per year. Copyright Copyright (C) 2021 The Author(s). Published by Wolters Kluwer Health, Inc. on behalf of the American Academy of Neurology.. All rights reserved. Print ISSN: 0028-3878. Online ISSN: 1526-632X.

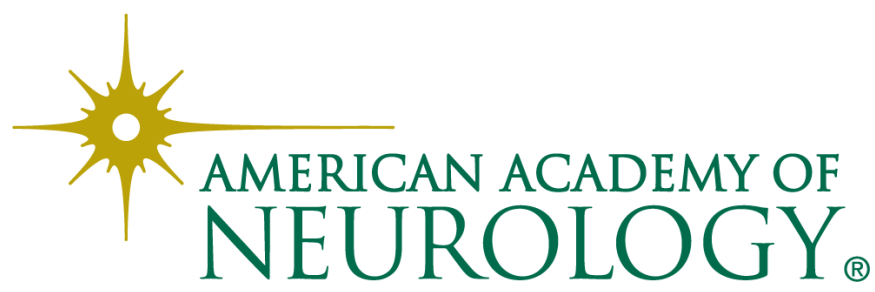

